\title{
Strategi Filosofis Masyarakat Jepang Dalam Mengatasi Dilema Budaya Kerja Di Masa Pandemi Covid-19
}

\author{
Iriyanto Widisuseno \\ Program Studi Bahasa dan Kebudayaan Jepang, Fakultas Ilmu Budaya, \\ Universitas Diponegoro Semarang, Jawa Tengah - Indonesia \\ widisusenoiriyanto@yahoo.co.id
}

\begin{abstract}
For the Japanese people, the remote work policy which aims to break the chain of the spread of the Corona-19 Virus is a cultural dilemma, because it clashes with the work culture of the people who have a strong work ethic. But in fact, Japan's economic recession rate is not as bad as other developed countries, such as America, China, and Korea. The death rate from Covid-19 is very low. Currently, Japan has started to return to normal its national economy. The mystery behind it all in Japan is the factor of superior immunity or cultural superiority. The assumption is, if because of the cultural superiority factor, what are the basic values that underlie the formation of behavior and culture of Japanese society. This philosophical qualitative study aims to examine philosophical strategies: what are the basic values that underlie the way Japanese people think and behave in the face of the Covid-19 pandemic, how to properly solve problems (epistemology), and what normative rules are used to give direction to achieve goals (axiology). Through philosophical descriptive methods, this research can reveal the philosophical values (ontological, epistemological, axiological) behind social phenomena in Japanese society. The results of the study show that Japanese people hold firmly to the value of discipline as an ontological footing, the samurai is used as a way to solve problems, the value of harmony as a normative rule that gives direction to the achievement of goals. The benefits of this research provide enlightenment for the community about understanding the basic problems in society that are often neglected, while many people only focus on the surface of the problem that causes failure to understand.
\end{abstract}

Keywords: Japanese society; philosophical strategy; the Covid-19 pandemic; work dilemma

\section{Pendahuluan}

Secara umum penelitian strategi filosofis mengenai masalah budaya merupakan reaksi terhadap dunia pemikiran manusia dewasa ini yang positivistik, sedang mengalami perubahan secara mendasar ke arah keterbukaan kreatif, meletakkan unsur kritik sebagai bagian cara mencapai kebenaran. Segala kebenaran pengetahuan dan realitas kehidupan serba terukur sejauh mana masuk akal dan dapat diverifikasi secara empiris. (Widisuseno, Iriyanto, 2006). Kebiasaan cara berfikir positivistik pada masyarakat bangsa barat akan menjadi tidak mudah bagi mereka untuk dapat memahami dimensi metafisis kebudayaan yang memberi arti kemanusiaan secara utuh. Kebudayaan manusia harus dilihat dari keseluruhan kompleksitasnya yang mencerminkan hakikat manusia utuh yang berbudaya. Kebudayaan sebagai representasi kemanusiaan tidak dapat dipahami hanya dari sisi rasional dan empiris saja, aspek metafisis tidak bisa diabaikan karena aspek ini memberi makna keunikan kebudayaan suatu bangsa.

Penelitian ini mengkaji kebudayaan Jepang, sebagai salah satu negara yang sangat menjunjung tinggi nilai-nilai budaya. Kelebihan Jepang adalah mampu mempertahankan nilai kebudayaanya sebagai landasan metafisis pengembangan ilmu pengetahuan dan teknologi dan kehidupan masyarakat sehari-hari. Hal ini tercermin dalam pola kehidupan masyarakat Jepang yang menggambarkan keharmonisan perpaduan modern dan tradisional. Keharmonisan tersebut bisa dilihat dari kemajuan ilmu pengetahuan, teknologi dan industri tanpa mengabaikan ataupun meninggalkan nilainilai budaya yang mereka miliki. Sementara beberapa negara lain saat ini sedang menghadapi problem jati diri bangsa, akibat dampak perkembangan teknologi modern. Saat ini keunikan budaya yang dimiliki oleh masyarakat 
Jepang tetap menjadi bagian dari kehidupan mereka di jaman modern. Jepang memiliki dasar nilai-nilai budaya disiplin atau dalam Bahasa Jepang shitsuke, artinya ketaatan, kepatuhan pada aturan. Nilai-nilai budaya disiplin inilah yang membentuk budaya kerja Jepang dan menjadikan sebagai negara maju di tingkat dunia. Sejak 1950 atau pasca Perang Dunia II, Jepang menjadi salah satu negara yang menjadi tolok ukur budaya "kerja keras" di seluruh dunia. Dalam masa keemasan pertumbuhan ekonominya, perusahaan-perusahaan Jepang menawarkan keamanan kerja seumur hidup dan upah yang tinggi sebagai imbalan atas jam kerja yang panjang, kesetiaan, dan totalitas dalam pelayanan. Budaya kerja Jepang ini telah berimplikasi pada lahirnya citra Jepang di dunia internasional sebagai negara yang "workaholic" (Widarahesti, Yusi, 2020).

Dunia telah mengakui kebudayaan Jepang memiliki keunikan budaya tersendiri, sangat menarik untuk dikaji secara filosofis. Belajar dari kebudayaan Jepang dapat memperoleh pengalaman nilai-nilai metafisis/ filosofis yang membentuk jati diri bangsa Jepang yang dikenal tangguh dalam mengatasi segala tantangan hidup. Sejumlah pengalaman metafisis misalnya, nilai kedisiplinan, etos kerja, etika sopan santun, integritas dan kerja keras. Penelitian ini mengkaji cara bangsa Jepang memainkan peran filsafat hidupnya dalam mengatasi dilema budaya selama pandemi Covid-19. Masyarakat Jepang menerapkan strategi filosofis kehidupan yang membentuk etos kerja yang kuat.

Pendekatan filosofis menjadi sangat penting karena dapat mengantarkan jalan penelitian ini untuk mengenali lebih mendalam tentang siapa bangsa Jepang itu dengan segala keunikan kulturnya dalam menghadapi masa pandemi Covid -19. Penelitian dapat mengungkap dilema budaya, bagaimana masyarakat Jepang dapat menjaga budaya etos kerja yang sudah mengakar di satu sisi, dan di sisi lain mereka dihadapkan pada kompleksitas persoalan dampak pandemic Covid-19 yang harus dijawab sebagai persoalan internal bangsa Jepang. Persoalan dilematik selalu menempatkan dua persoalan yang sama beratnya dan harus ada jawaban alternatif secara bijak (Widisuseno, Iriyanto, 2019).

\section{Metode}

Sesuai dengan tujuan penelitian kualitatif ini, untuk memperoleh data penelitian menggunakan sumber literature dan metode analisis deskriptif filosofis. Penelitian ini fokus pada masalah bagaimana masyarakat Jepang dalam memainkan peran filsafat dan pndangan hidupnya ketika menghadapi dilemma kultural selama pandemic Covid-19. Penelitian kualitatif digunakan untuk mengungkap aspek kualitatif fenomena sosial budaya masyarakat (Robert Bogdan dan Taylor, 1992). Langkah-langkah metode filosofis melalui tahap analisis esensial, komprehensif dan normative. Tahap analisis esensial menggali azas ontologis, tahap analisis komprehensif menggali azas epistemologis, tahap analisis normative untuk menggali azas aksiologis. Azas ontologis, menggambarkan bagaimana orang Jepang dalam mengkonsepsikan arti dan makna hakiki kehidupan masa pandemic Covid-19. Hasil pemahaman azas ontologis ini memberi landasan asumsi yang dapat digunakan sebagai pijakan atau pegangan bagi keberadaan hidup orang Jepang. Azas epistemologi, menggambarkan cara orang Jepang mewujudkan konsep arti dan makna hakiki kehidupan di tengah dunianya. Azas aksiologis, menggambarkan nilainilai yang menjadikan arah atau tujuan hidup. Keberadaan ketiga azas eksistensi terebut saling beririsan dan sistemik (Widisuseno, Iriyanto, 2012). Dalam 
kontek penelitian ini, untuk membedah relasi peran strategi filosofis dalam mengatasi dilemma budaya masyarakat Jepang dijelaskan dengan teori nilai Robin M. Williams. Teori nilai tersebut menjelaskan, nilai merupakan unsur penting dan tidak dapat disepelekan bagi orang yang bersangkutan. Dalam kenyataan, nilai berhubungan dengan pilihan, dan pilihan merupakan prasyarat untuk mengambil suatu tindakan (Sulaiman, 1993). Pendekatan strategi filosofis dalam penelitian ini mengungkap pentingnya nilai. Nilai secara intrinsic bersifat filosofis dan secara ekstrinsik berupa pandangan hidup. Nilai-nilai tersebut merupakan kebulatan ajaran tentang berbagai bidang kehidupan masyarakat bangsa Jepang. Ajaran filsafat tersebut sedemikian kuat mempengaruhi alam pikiran orang Jepang, berupa cara pandangnya mengenai arti hidup dan kehidupan, masyarakat dan negara. Sebagai manifestasinya dalam kehidupan berbangsa dan bernegara, nilai-nilai diyakini sebagai nilai dasar, dan puncak budaya bangsa, jiwa dan memberi watak bangsa Jepang, maka sangat beralasan untuk memberi pengakuan terhadap kedudukan nilai sebagai filsafat bangsa Jepang.

\section{Hasil dan Pembahasan}

\subsection{Azas Ontologis}

Azas ontologis bagi masyarakat Jepang dalam menghadapi masa pandemi Covid-19 yaitu disiplin. Disiplin adalah nilai-nilai dasar yang menjadi acuan dan identitas nasional bangsa Jepang, sebagai bagian dari sikap positif bangsa Jepang yang tekun, rajin, kerja keras, dan tepat waktu demi kemuliaan hidup. Masyarakat Jepang dalam menghadapi masa pandemic Covid-19 meletakkan nilai kedisiplinan sebagai landasan membentuk budaya kerja keras. Budaya kerja bagi masyarakat Jepang sudah merupakan nilai bangsa (Widarahesty,
Yusi, 2020). Menurut penjelasan Teori nilai, bahwa budaya kerja masyarakat Jepang yang merupakan nilai bangsa menjadi watak atau karakter bangsa Jepang. Disiplin dikaitkan dengan harga diri, jika mereka mengalami kegagalan maka pekerja atau individu tersebut yang akan menanggung malu, bukan perusahaan atau organisasi tempat mereka bernaung (Ann Wan Seng, 2007). Sehingga isu adaptasi dalam masa pandemic Covid-19 bagi masyarakat Jepang menjadi dilema kultural tersendiri yang berbenturan dengan budaya kerja masyarakat Jepang. Budaya kerja masyarakat Jepang yang workaholic minded, dan "grouporiented society menyebabkan imbauan kerja jarak jauh menjadi sulit untuk diwujudkan di Jepang. (Widarahesty,Yusi, 2020). Sisi kelemahan dari budaya kerja keras di Jepang adalah over time system yang membawa akibat buruk pada pekerja, misalnya rasa kejenuhan menimbulkan stres dan keinginan bunuh diri.

Untuk memberi penjelasan masalah dilemma kultural tersebut, teori nilai sebagai pendekatan sfilosofis dapat memberi jalan pemikiran solutif, bahwa masa pandemic Covid-19 bagi masyarakat Jepang dapat diartikan masa transformasi budaya, yaitu proses perubahan dari tradisi budaya lama ke tatanan kehidupan normal yang baru. Misalnya, dalam adaptasi new noral, work from home, social distancing, di situ terdapat proses akulturasi antara budaya kerja Jepang dengan budaya protocol kesehatan masa pandemic Covid-19. Pada kesempatan tersebut sebenarnya bisa menjadi peluang bagi masyarakat Jepang sebagai ajang untuk mengimplementasikan kebijakan pemerintah terkait "work life balance" yang selama ini dikampanyekan oleh pemerintah dan juga lembaga-lembaga swadaya masyarakat untuk menekan tingkat stres yang tinggi akibat budaya kerja yang buruk. (Tokyoreview dalam 
Widarahesty, Yusi 2020). Bangsa Jepang sendiri sebetulnya sudah lama mempraktikan budaya harmoni dalam kehidupan. Budaya harmoni merupakan warisan ajaran Confusianisme, misal tidak merugikan orang lain, menjaga lingkungan. Praktik work life balance bukan hal yang baru bagi masyarakat Jepang. Perubahan kultur baru yang diperlukan untuk menghadapi dilemma kultural masa pandemic Covid-19 hanya pada masalah proses akulturasi, dari pola linier berubah ke pola dialektik (Widisuseno, Iriyanto, 2017).

\subsection{Azas Epistemologis}

Bagaimana azas epistemologis bagi masyarakat Jepang dalam meletakkan nilai dasar disiplin dapat membangun budaya kerja untuk menghadapi pandemic Covid-19. Fakta historis ditemukan, setelah masa restorasi Meiji 1868, Jepang berusaha keras untuk mengangkat negaranya ke level yang sama dengan kekuatan Barat yang pada saat itu menjadi kekuatan dominan dengan cara meningkatkan kekuatan industri negaranya Jepang berhasil mengubah masyarakat feodal menjadi negara industri penuh yang hanya dalam waktu singkat, tentunya menyebabkan Jepang membutuhkan banyak tenaga kerja (Nippon, dalam Widarahesty,Yusi, 2020). Teori nilai dapat menjelaskan temuan fakta historis tersebut, bahwa pemerintah Jepang memiliki standar kebenaran yang bertumpu pada industrialisasi. Proses perkembangannya melalui pola dialektika, terbuka dan mengadopsi teknologi dari luar. Cara mengkonsepsikan kebenaran epistemologisnya melalui sintesis aposteriori. Pola berfikir epistemologi semacam ini sangat progress dan dinamis, itulah mengapa Jepang bisa berkembang sebagai negara maju dengan cepat dan mampu bertahan menghadapi tantangan hidup. Kekuatan budaya Jepang terletak pada kemampuan proses, sehingga membentuk budaya kerja keras, disiplin.

Proses dialektika budaya Jepang yang mampu mengadaptasi budaya barat dengan tujuan memajukan budaya kerja Jepang sendiri adalah sebuah keunikan epistemologis yang tidak semua bangsa memilikinya. Contoh dalam sejarah, Pengalaman Jepang ketika menghadapi kekalahan Perang Duni II, Kota Nagasaki dan Hiroshima hancur dibom atom oleh Amerika dan sekutunya, justru pemerintah Jepang segera mengirimkan para guru sekolah untuk belajar di Amerika Serikat. Dengan harapan para guru dapat mencerap ilmu pengetahuan dan teknologi modern Amerika yang dapat mengalahkan Jepang, untuk suatu saat dikembangkan di Jepang.

Keunikan epistemologis bangsa Jepang terletak pada kemampuan masyarakat Jepang dalam mengadaptasi dan mengadopsi nilai budaya Barat tidak mengakibatkan erosi kebuadayaan sendiri. Bahkan hebatnya, justru nilainilai budaya asing untuk memperkuat budaya nasional sendiri. Kebanyakan bangsa lain justru merasa terganggu dengan masuknya budaya asing. Jadi, dalam masyarakat Jepang, setiap individu sudah memiliki kerangka berfikir ontologis yang kuat, sehingga dalam praktik epistemologisnya sudah punya keranga dan pondasi kuat. Berbeda ketika di Indonesia saat ini, masyarakat Indonesia sangat lemah kerrang ontologisnya, sehingga ketika menghadapi gelombang peerubahan dari luar muday goyah, tergalaukan, hilang jati diri.

Sebagai manifestasi kekuatan epistemologis Masyarakat Jepang, terlihat budaya kerja keras, disiplin, tidak mudah menyerah, dan loyallitas tinggi, sudah tertanam dalam kebiasaan hidup seharihari masyarakat Jepang ketika bekerja di kantor, perusahaan. Etos kerja semacam inilah yang mengantarkan bangsa Jepang bangkit dari keterpurukan ekonomi, sosial 
budaya dan krisis lainnya akibat dari pandemi Covid-19.

\subsection{Azas Aksiologis}

Bagaimana azas aksiologis masyarakat Jepang dalam menetapkan kaidah normative budaya kerja dalam mengatasi dilemma budaya saat pandemi Covid-19. Teori nilai memberi penjelasan bahwa setiap objek apapun, termasuk perilaku dan budaya manusia mengandung nilai. Artinya, ada tujuan tertentu, ada harganya, ada maknanya dalam setiap perilaku dan budaya manusia. Pengertian nilai dapat merujuk pada entitas material, sosial, spiritual, ekonomis, dan fisik. Kaidah normative budaya kerja Jepang dapat dijelaskan melalui temuan fakta sosial di lapangan seperti berikut.

\subsubsection{Kebersamaan $(\mathrm{Wa})$}

$W a$ memiliki makna kebersamaan yang berorientasi pada nilai-nilai yang bersifat kualitatif, tidak dapat diukur, yakni seishin spirit / semangat, kimochi (emosi/perasaan), omoiyori (pertimbangan), chugisei (loyalitas). "Wa" yang biasa disebut dengan istilah nakama ishiki memiliki makna perasaan akrab atau erat yang dimiliki antara anggota sesama masyarakat atau antara anggota masyarakat dengan pemimipin-pemimpinnya. Seishin (semangat) nilai-nilai ini akan tampak pada saat kita melakukan komunikasi dengan orang Jepang, mereka selalu memberikan pujian agar orang yang ada didepannya merasa termotifasi dengan apa yang dilakukannya. Misalnya apabila ada orang asing yang bisa berbicara dalam Bahasa Jepang meskipun kemampuannya masih terbatas mereka akan selalu mengatakan nihongo ga jouzu desu ne, artinya kaåmu pandai sekali dalam berbahasa Jepang

\subsubsection{Kimochi (emosi)}

Dalam berkomunikasi orang Jepang selalu mejaga perasaan orang yang ada di depannya, hal ini bisa kita lihat pada saat melakukan komunikasi orang Jepang tidak pernah berkata tidak secara terbuka untuk melakukan penolakan dalam menyampaikan pendapat, mereka selalu mengedepankan kondisi dan tidak menyatakannya secara terbuka.

\subsubsection{Omoiyori (pertimbangan)}

Orang Jepang dalam mengambil keputusan selalu dilandasi dengan pertimbangan yang sangat matang, mereka lebih mengutamakan pentingnya membangun hubungan yang kuat dengan dilandasi kepercayaan dan kepentingan bersama. Dalam berkomunikasi nilai-nilai dari orang Jepang sangat mempertimbangkan perasaan orang yang dihadapannya untuk menjaga dan membina hubungan baik diantara keduanya (Saronto, Budi, 2005).

\section{Kesimpulan}

Bangsa Jepang memiliki kemampun dan komitmen tinggi untuk memegang teguh strategi filosofisnya dalam menghadapi dilemma budaya saat pandemic Covid-19. Keefektifan strategi filosofi bangsa Jepang bertumpu pada nilai-nilai disiplin sebagai landasan ontologis untuk membangun budaya kerja keras. Pokok persoalan dilemma budaya dalam menghadapi pandemic Covid-19 adalah pada kemampuan berakulturasi setiap warga masyarakat dengan budaya new normal. Problem dilemma budaya yang memberi tantangan bagi Jepang dalam menghadapi pandemic Covid-19 adalah melakukan perubahan budaya kerja melalui kerja jarak jauh. Masa pandemic Covid-19 bisa menjadi peluang bagi masyarakat Jepang sebagai ajang untuk mengimplementasikan kebijakan pemerintah terkait "work life balance" untuk menekan tingkat stres yang tinggi akibat dampak budaya kerja yang overtime. Jasil penelitian ini menyadarkan kepada kita semua, bahwa penanggulangan Covid-19 kuncinya terletak pada kesediaan setiap warga masyarakat untuk mengubah perilaku dan budaya hidup sehat, dan sadar lingkungan.

\section{Daftar Referensi}


Abidin Zainal, Filsafat Manusia, Memahami Manusia Melalui Filsafat, Bandung: PT. Remaja Rosda Karya, 2000.

Achmadi Asmoro, Pengantar Filsafat Umum, Jakarta: Raja Grafindo Persada, 2005 .

Ahmad Zaenal Abidin, Riwayat Hidup Ibn Rusyd, Jakara: Bulan Bintang, 1975.

Al-Ahwani Ahmad Fuad, Filsafat Islam,Jakarta: Pustaka Firdaus, 1997.

Al-Ahwany Ahmad Fu`ad, al-Falsafah alIslamiyyah, Kairo: Maktaba alSaqafiyyat, 1962.

Al-Ghamimi Abu al-Wafa, Sufi Dari Zaman ke Zaman, terj Afif Muhmmad, Bandung: Pustaka Setia, 1998.

Al-Ghazali, Tahafut al-Falasifah, Mesir: Dar al-Ma'arif, 1966

Al-Iraqi Muhammad Athif, Al-Naz'ah alAqliyah fi Falsafah Ibn Rusyd, Kairo: Dar al-Ma;arif, 1979

Aminrazavi Mehdi, Pendekatan Rasional Suhrawardi Terhadap Problem Ilmu Pengetahuan, dalam jurnal Al-Hikmah, Bandung: edisi 7 Desember, 1992
Robert Bogdan dan Taylor, 1992.

Pengantar Metode Penelitian

Kualitatif,Terjemahan oleh Arief Rurchan, Usaha Nasional, Surabaya.

Widarahesti, Yusi, 2020). Persoalan Dilema Budaya Kerja di Tengah Pandemi Covid-19

Jepang,http://psdr.lipi.go.id/news-andevents/opinions/dilema-budaya-kerjajepang-di-tengah-pandemi-covid-19-edisikhusus-covid-19-bagian-13.html. Diakses Tgl 16 Juni.

Widisuseno, Iriyanto, 2006. Arti dan Proses Pertumbuhan Pengetahuan Ilmiah dalam Perspektif Rasionalisme Kritis Karl. R. Popper, Disertasi, Universitas Gadjah Mada, Yogyakarta.

Widisuseno, Iriyanto, 2019. Etika Taoisme dan Implementasinya, Undip Press, Semarang.

Widisuseno, Iriyanto, 2012. Peran Filsafat dalam Menghadapi Persoalan Perkembangan Ilmu dan Teknologi di Indonesia, Undip Press, Semarang.

Widisuseno, Iriyanto, 2017. Teori Pertumbuhan Pengetahuan Ilmiah Karl. R. Popper dan Implementasinya di Indonesia, Undip Press, Semarang. 